\title{
Cetacean sightings and acoustic detections during a seismic survey off Nicaragua and Costa Rica, November-December 2004
}

\author{
Meike Holst ${ }^{1}$, Mari A. Smultea ${ }^{1,2}$, William R. Koski ${ }^{1}$, Alejandro J. Sayegh ${ }^{3}$, Gianni Pavan ${ }^{4}$,
} Joseph Beland ${ }^{5,6} \&$ Howard H. Goldstein ${ }^{5,7}$

1. LGL Limited, environmental research associates, 22 Fisher St., P.O. Box 280, King City, ON, L7B 1A6, Canada; mholst@lgl.com, bkoski@lgl.com

2. Current address: Smultea Environmental Sciences (SES), P.O. Box 256, Preston, WA 98050, USA; mari@smulteasciences.com

3. CIC, Centro de Investigación de Cetáceos, E/S Los Robles, Av. Jóvito Villalba, Sector Los Robles, 6316, Isla de Margarita, Venezuela; asayeghr@gmail.com

4. Department of Earth and Environmental Sciences, CIBRA, University of Pavia, Via Taramelli 24, 27100, Pavia, Italy; gianni.pavan@unipv.it

5. Lamont-Doherty Earth Observatory, Columbia University, 61 Route 9W, P.O. Box 1000, Palisades, NY, 10964-8000, USA

6. Current address: LGL Limited, 22 Fisher St., P.O. Box 280, King City, ON, L7B 1A6, Canada; jbeland@1gl.com

7. Current address: National Oceanic and Atmospheric Administration (NOAA), National Marine Fisheries Service (NMFS), Office of Protected Resources, 1315 East-West Hwy, Silver Spring, MD, 20910-3226, USA; howard.goldstein@noaa.gov

\section{Received 05-VII-2016. Corrected 09-XII-2016. Accepted 10-I-2017.}

\begin{abstract}
Although the wider Eastern Tropical Pacific has been systematically surveyed during summer/fall, relatively little effort has focused on shelf and slope waters of Nicaragua and Costa Rica. Such data are useful for establishing baseline information and assessing potential changes in cetacean occurrence and distribution relative to natural (e.g., El Niño-Southern Oscillation, climate change) and anthropogenic factors. A visualacoustic survey for cetaceans occurred as part of a monitoring and mitigation program during an academic geophysical seismic study off Nicaragua and Costa Rica, during November-December 2004. Approximately 2067 cetaceans representing at least seven species were seen in 75 groups during $373 \mathrm{~h}(3416 \mathrm{~km})$ of daytime observations from the seismic research vessel (R/V) Maurice Ewing. The humpback whale (Megaptera novaeangliae) and the pantropical spotted dolphin (Stenella attenuata) were the most frequently sighted species $(30 \%$ of all groups sighted); both were seen in shelf waters $<100 \mathrm{~m}$ deep and in slope waters. The bottlenose dolphin (Tursiops truncatus; $10 \%$ of sightings) was the third most frequently sighted species and was only seen in water $>100 \mathrm{~m}$ deep. In addition, sightings were made of spinner dolphins (S. longirostris), short-beaked common dolphins (Delphinus delphis), Risso's dolphins (Grampus griseus), short-finned pilot whales (Globicephala macrorhynchus), and unidentified dolphins and whales. Unconfirmed sightings of a minke whale (Balaenoptera acutorostrata) and a pod of false killer whales (Pseudorca crassidens) were also recorded. An additional six groups of dolphins (50\% confirmed to species, all pantropical spotted dolphins) were made during $187 \mathrm{~h} \mathrm{(1549}$ $\mathrm{km}$ ) of observation effort during darkness, two of which were detected within $30 \mathrm{~m}$ of the vessel bow using a night vision device. A total of 217 cetacean detections occurred during $633 \mathrm{~h}$ of passive acoustic monitoring. A small concentration of 12 humpback whales was seen in eight groups, and two humpbacks were recorded singing in the Gulf of Fonseca on 9 December 2004. To our knowledge, such concentrations of humpback whales, particularly singing humpbacks, have not been previously reported in this specific area. In addition, a humpback mother-calf pair, likely from the Northern Hemisphere population, was seen off Northern Costa Rica on 25 November 2004. Although cetacean sighting rates were significantly different during seismic and non-seismic periods even when corrected for differential detection probability related to sea conditions, our survey results do provide information to address previous data gaps on cetacean occurrence in shelf and slope waters off the Pacific coast of Central America during late fall. Rev. Biol. Trop. 65 (2): 599-611. Epub 2017 June 01.
\end{abstract}

Key words: geophysical survey, passive acoustic monitoring, marine mammal, Eastern Tropical Pacific, Central America. 
Cetacean distribution and abundance in deep pelagic waters of the Eastern Tropical Pacific (ETP) has been systematically studied for > 30 years (Polacheck, 1987; Reilly, 1990; Wade \& Gerrodette, 1993; Ferguson \& Barlow, 2001; Ferguson, Barlow, Fiedler, Reilly, \& Gerrodette, 2006; Rankin, Barlow, Oswald, \& Ballance, 2008; Hamilton et al., 2009; Forney et al., 2012; Barlow, 2015). However, such information from neritic waters is generally lacking for Western Nicaragua and Honduras, though better described for Costa Rica (May-Collado, Gerrodette, Calambokidis, Rasmussen, \& Sereg, 2005; Martínez-Fernández, Montero-Cordero, \& May-Collado, 2011). The spotted dolphin (Stenella attenuata), bottlenose dolphin (Tursiops truncatus), and humpback whale (Megaptera novaeangliae) are the most frequently sighted cetacean species in coastal waters of Western Costa Rica (May-Collado et al., 2005; Martínez-Fernández et al., 2011; May-Collado \& Forcada 2012).

During November-December 2004, we conducted visual observations and $24 \mathrm{~h}$ per day passive acoustic monitoring (PAM) of cetaceans in shelf and continental slope waters off Western Nicaragua and Costa Rica, as part of a requisite marine mammal monitoring and mitigation program for Lamont-Doherty Earth Observatory's (L-DEO) seismic survey for geophysical research in the ETP. This study was not designed as a systematic cetacean survey, but rather as part of a program to reduce potential effects of seismic survey operations on marine mammals. Standard mitigation measures implemented during the seismic survey included ramp-up, power-down, and shut-down procedures (Nowacek et al., 2013; Wright \& Cosentino, 2015). Nonetheless, a substantial amount of data on the occurrence and distribution of cetacean species was collected predominantly along a priori systematic survey lines.

Although localized and short-term behavioral responses have been reported for some cetaceans during seismic surveys (Richardson, Greene, Malme, \& Thomson, 1995; Gordon et al., 1998; Nowacek, Thorne, Johnston, \& Tyack, 2007; Southall et al., 2007), our survey results address previous data gaps on the cetacean occurrence in shelf and slope waters off the Pacific coast of Central America during late fall. We also demonstrate the utility of using two common cetacean monitoring techniques (visual observations and PAM), document detection of dolphins during periods of darkness using a night vision device (NVD), and summarize mitigation and monitoring measures implemented during the course of the study. Lastly, we examine the potential effects the seismic source had on delphinid encounter rates.

\section{MATERIALS AND METHODS}

Survey vessel: The R/V Maurice Ewing (Ewing) was used for this seismic study. The Ewing was $70 \mathrm{~m}$ long, with a beam of $14.1 \mathrm{~m}$ and a draft of $4.4 \mathrm{~m}$. During the seismic survey, the vessel towed three Generator Injector (GI) airguns with a total discharge volume of $315 \mathrm{in}^{3}$ and a source level of $240.7 \mathrm{~dB}$ re $1 \mu \mathrm{Pa} \cdot \mathrm{m}$ $(0-p k)$. All three airguns were in operation $81 \%$ of the time; one or two airguns were in operation during the remainder of operations. Seismic pulses were $200 \mathrm{~ms}$ in duration at the source and were emitted every $5 \mathrm{~s}$ along $a$ priori systematic transect lines. During seismic acquisition, the vessel traveled at a speed of 7-9 km/h; when not towing gear (e.g., during transits to the study area), the Ewing cruised at $18-20 \mathrm{~km} / \mathrm{h}$.

Study area: The Ewing departed Puntarenas, Costa Rica, on 21 November 2004; visual observations started when the vessel left port. The seismic study encompassed the area between $10^{\circ}-13^{\circ} \mathrm{N} \& 86^{\circ}-88^{\circ} \mathrm{W}$ in the ETP off the coasts of Costa Rica, Honduras, Nicaragua, and El Salvador (Fig. 1). Seismic operations and PAM commenced on 22 November. The vessel finished seismic operations and PAM on 20 December. Visual observations ended on 21 December, when the vessel arrived in Balboa, Panama. Water depths in the study area ranged from 20 to $5000 \mathrm{~m}$. 


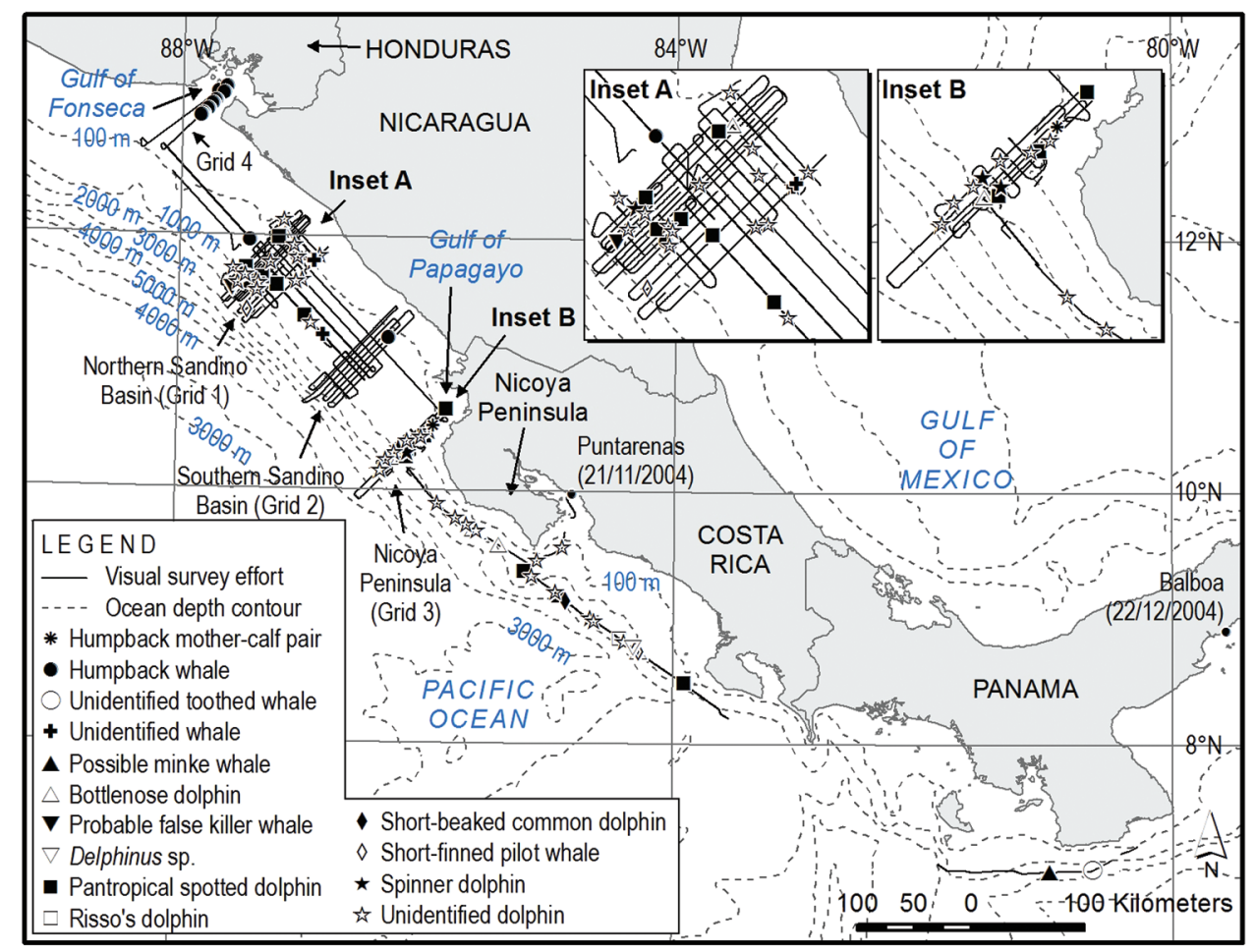

Fig. 1. Locations of cetacean sightings made during the L-DEO seismic survey, 21 November-22 December 2004.

Visual observations: Observations for cetaceans occurred from the Ewing's flying bridge (14.4 masl), or during inclement weather from the bridge (11 masl). One or two observers were on duty during all daytime airgun operations and during most periods without airgun operations during daylight. Observers alternated between $7 \times 50$ reticle binoculars, $25 \times 150$ big-eye binoculars, and the naked eye to monitor for cetaceans around the vessel. Observation effort focused $180^{\circ}$ in front of vessel with occasional search sweeps outside of this range. Visual monitoring occurred during some nighttime operations and was conducted with the naked eye and an NVD that provided $4 \mathrm{x}$ magnification and an approximate $40^{\circ}$ field of view.

While on visual watch, observers systematically recorded vessel activities and observation conditions on a data entry form every $30 \mathrm{~min}$, as activities allowed. For all entry records, the date, time, vessel position (latitude, longitude), and environmental conditions (glare, visibility, Beaufort wind force [Bf]) were recorded. Environmental conditions also were recorded whenever they changed and with each sighting record. Standardized codes were used for each record along with written comments as relevant. Operational activities that were recorded included the number of GI airguns in use and the type of vessel/seismic activity. For each cetacean sighting, the species, identification reliability, number of individuals, and vessel position and activity were recorded.

Passive acoustic monitoring: PAM occurred $24 \mathrm{~h}$ per day during seismic operations to detect vocalizing cetaceans and aid visual observers by alerting them of the occurrence and location (when possible) of vocalizing cetaceans, particularly during periods with reduced visibility such as darkness. PAM did not occur during periods without seismic 
operations, as it was not possible to deploy the PAM array during line changes. SEAMAP software (version 1.525, Houston, TX) was used to acoustically monitor a bandwidth of $\sim 0.5-24 \mathrm{kHz}$. Two of four hydrophones in the active section of the array were monitored at a time. The length of the lead-in from the hydrophone array was $240 \mathrm{~m}$, and the active part of the array was $56 \mathrm{~m}$ long. The array was towed at a depth of $20 \mathrm{~m}$ or less, depending on bottom depth. PAM occurred below deck in a wet laboratory by one experienced PAM operator. Headphones and/or speakers and spectrographic images were used to detect, display, and classify cetacean vocalizations in real time (and post-detection) on a monitor (SeaPro, CIBRA, University of Pavia, Italy) (Pavan, Fossati, Manghi, \& Priano, 2004). Acoustic detections were logged on a dedicated database and mapped on a navigation display. Acoustic detections were only identified to species if they were confirmed visually.

Encounter rates: Cetacean encounter rates per unit effort were determined for non-seismic and seismic periods. Non-seismic periods included only data collected before or over $6 \mathrm{~h}$ after seismic operations had ceased. The $6 \mathrm{~h}$ time period was used to distinguish seismic periods from those periods where seismic surveys were sufficiently far in the past that it could be assumed that they had no effect on current cetacean behavior and distribution. Thus, effort and sightings that occurred within this $6 \mathrm{~h}$ period were excluded from the analyses. In addition, only data obtained during $\mathrm{Bf} \leq 5$ and when the vessel traveled at speeds over $3.7 \mathrm{~km} / \mathrm{h}$ were used for determining encounter rates. In addition, encounter rates were also adjusted to account for difference in detection rate based on Beaufort wind force conditions using Table 3 in Barlow (2015). Encounter rates (number of groups $/ \mathrm{km}$ ) were determined for each species for three water depth categories: shallow $(<100 \mathrm{~m})$, intermediate $(100$ to $1000 \mathrm{~m})$, and deep $(>1000 \mathrm{~m})$ roughly corresponding with shelf, continental slope, and pelagic waters, respectively. A chi-square test $\left(\chi^{2}\right)$ was used to examine differences between encounter rates during seismic and non-seismic periods.

Mitigation measures: Standard mitigation measures implemented during the seismic survey included ramp-up, power-down, and shut-down procedures. A ramp-up procedure was implemented whenever the 3-GI airgun array was powered up, to gradually increase the volume of the operating source at a rate no greater than one additional airgun per $5 \mathrm{~min}$. If a cetacean was sighted within designated safety zones, a power down to a single airgun or shut down of all three airguns was implemented. The safety zones varied with array size and water depth and ranged from $27 \mathrm{~m}$ for a single airgun in deep water to $574 \mathrm{~m}$ for three airguns in shallow water.

\section{RESULTS}

Daylight visual observations: During daylight, a total of $373 \mathrm{~h}(3416 \mathrm{~km})$ of visual observations occurred from the Ewing, of which $86 \%$ took place during seismic operations. Two observers were on duty $57 \%$ of the total $373 \mathrm{~h}$ of observation time, with one observer on duty for the remaining $160 \mathrm{~h}$. Observers watched for cetaceans during all daylight hours when the GI airguns were operating and during most $(89 \%)$ daylight hours when the vessel was underway with no GI airguns operating. Most observation effort occurred in BF 4 and 5.

A total of 75 cetacean groups $(\sim 2067$ individuals) were sighted, representing at least seven confirmed species (Table 1; Fig. 1). The pantropical spotted dolphin and humpback whale were the most frequently sighted species in terms of groups (13 and 11 sightings, respectively), followed by the common bottlenose dolphin (8 groups) and the short-finned pilot whale (Globicephala macrorhynchus; 4 groups). On an individual basis, more spinner dolphins (S. longirostris) were seen $(\sim 1350$ individuals in 3 groups) than any other cetacean species, followed by pantropical spotted (238 individuals) and common bottlenose dolphins (69 individuals). Single sightings of each 
TABLE 1

Number of visual and acoustic detections of cetacean groups (and individuals) from the Ewing during the L-DEO survey off the Pacific coast of Costa Rica, Nicaragua, and Gulf of Fonseca ${ }^{\mathrm{a}}$

\begin{tabular}{|c|c|c|c|c|c|}
\hline \multirow[b]{2}{*}{ Species } & \multirow[b]{2}{*}{$\begin{array}{l}\text { Visual-Only } \\
\text { Sightings }\end{array}$} & \multirow[b]{2}{*}{$\begin{array}{l}\text { Acoustic-Only } \\
\text { Detections }\end{array}$} & \multirow[b]{2}{*}{$\begin{array}{l}\text { Matched Visual/ } \\
\text { Acoustic Detections }\end{array}$} & \multicolumn{2}{|l|}{ Total } \\
\hline & & & & Visual Sightings & $\begin{array}{c}\text { Acoustic } \\
\text { Detections }\end{array}$ \\
\hline Tursiops truncatus & $6(50)$ & - & $2(19)$ & $8(69)$ & 2 \\
\hline Stenella attenuata & $5(38)$ & - & $8(200)$ & Day: 10 (227) Night: 3 (11) & $14^{\mathrm{b}}$ \\
\hline Stenella longirostris & - & - & $3(1350)$ & $3(1350)$ & 3 \\
\hline Delphinus delphis & $1(45)$ & - & - & $1(45)$ & - \\
\hline Delphinus sp. & & - & - & $1(15)$ & - \\
\hline Grampus griseus & $1(25)$ & - & - & $1(25)$ & - \\
\hline Globicephala macrorhynchus & $3(25)$ & $1^{\mathrm{b}}$ & $1(5)$ & $4(30)$ & $1^{\mathrm{c}}$ \\
\hline Pseudorca crassidens ${ }^{\mathrm{d}}$ & - & - & $1(12)$ & $1(12)$ & 1 \\
\hline Unidentified dolphin & $20(197)$ & 180 & $13(81)^{\mathrm{e}}$ & Day: 30 (265) Night: 3(13) & 194 \\
\hline Megaptera novaeangliae & $9(12)$ & - & $2(4)$ & $11(16)$ & 2 \\
\hline Balaenoptera acutorostrata ${ }^{\mathrm{f}}$ & $1(1)$ & - & - & $1(1)$ & - \\
\hline Unidentified whale & $4(7)$ & - & - & $4(7)$ & - \\
\hline Total Cetaceans & $51(415)$ & 181 & $30(1671)$ & $81(2091)$ & $217^{\mathrm{b}}$ \\
\hline
\end{tabular}

a. Numbers in parentheses are number of individuals. For species encountered during the day and night, sightings are provided separately. For acoustic detections, group size was unknown unless there was a concurrent matched visual sighting.

b. Seven of these detections were of the same individual, as confirmed by visual sightings.

c. Possible detection of short-finned pilot whales during a detection of unidentified dolphins.

d. Probable identification.

e. One match was an acoustic detection that corresponded to two different visual sightings.

f. Possible identification.

of the following cetaceans were also made: short-beaked common dolphin (Delphinus delphis), unidentified common dolphin (Delphinus sp.), and Risso's dolphin (Grampus griseus). In addition, one probable sighting of a pod of false killer whales (Pseudorca crassidens) and a possible minke whale (Balaenoptera acutorostrata) were also made (Table 1).

We saw humpback whales most frequently in Western Nicaraguan waters $\sim 150$ km southeast of the Gulf of Fonseca (Fig. 1), corresponding with our greatest survey effort. In addition, we saw an apparently unusual concentration of 12 humpback whales in eight groups in the Gulf of Fonseca near the Honduras/El Salvador/Nicaragua borders on 9 December. Two of these individuals were also recorded singing. Except for one sighting in water 700-800 $\mathrm{m}$ deep off Nicaragua, all humpback whale sightings were in water with depths $<200 \mathrm{~m}$.
In general, encounter rates for various delphinid species were greater during nonseismic compared with seismic periods. After correcting for wind force conditions (Table 2), the differences in encounter rates for all delphinids combined were marginally statistically significant for two water-depth categories with more than $250 \mathrm{~km}$ of survey effort (intermediate depths: $\chi^{2}=5.40, \mathrm{P}=0.020$; deep water: $\chi^{2}=6.31, \mathrm{P}=0.012$ ). During non-seismic perio$\mathrm{ds}$, the bottlenose dolphin adjusted encounter rate was highest in intermediate water depths (0.026 groups $/ \mathrm{km})$, while the spotted dolphin encounter rate was highest in shallow water $(0.045$ groups $/ \mathrm{km})$. Common dolphins, Risso's dolphins, and pilot whales were only seen in deep water during non-seismic periods. The highest encounter rate for humpbacks occurred during seismic operations in shallow water (0.030 groups $/ \mathrm{km})$. Spinner dolphins and probable false killer whales were seen only during 
TABLE 2

Number of individuals (No.) and adjusted encounter (Enc.) rates of cetaceans during the L-DEO survey in different water depth categories during seismic and non-seismic periods. Sighting rates are adjusted for Beaufort wind force at the time of the sighting based on Table 3 in Barlow (2015)

\begin{tabular}{|c|c|c|c|c|c|c|c|c|c|c|c|c|}
\hline \multirow{2}{*}{$\begin{array}{l}\text { Water depth category / } \\
\text { observer effort }\end{array}$} & \multicolumn{6}{|c|}{ Seismic } & \multicolumn{6}{|c|}{ Non-Seismic } \\
\hline & & $\begin{array}{l}100 \mathrm{~m} / \\
346 \mathrm{~km}\end{array}$ & & $\begin{array}{l}-1000 \mathrm{~m} / \\
433 \mathrm{~km}\end{array}$ & & $\begin{array}{l}1000 \mathrm{~m} / \\
346 \mathrm{~km}\end{array}$ & & $\begin{array}{l}100 \mathrm{~m} / \\
42 \mathrm{~km}\end{array}$ & & $\begin{array}{l}-1000 \mathrm{~m} / \\
279 \mathrm{~km}\end{array}$ & & $\begin{array}{l}1000 \mathrm{~m} / \\
289 \mathrm{~km}\end{array}$ \\
\hline Species & No. & Enc. Rate & No. & Enc. Rate & No. & Enc. Rate & No. & Enc. Rate & No. & Enc. Rate & No. & Enc. Rate \\
\hline Tursiops truncatus & - & - & 1 & 0.003 & 1 & 0.005 & 0 & 0 & 4 & 0.026 & 2 & 0.009 \\
\hline Stenella attenuata & 1 & 0.005 & 4 & 0.009 & - & - & 1 & 0.045 & 1 & 0.009 & 1 & 0.012 \\
\hline Stenella longirostris & - & - & 3 & 0.005 & - & - & - & - & - & - & - & - \\
\hline Delphinus delphis & - & - & - & - & - & - & - & - & - & - & 1 & 0.007 \\
\hline Delphinus sp. & - & - & - & - & - & - & - & - & - & - & 1 & 0.007 \\
\hline Grampus griseus & - & - & - & - & - & - & - & - & - & - & 1 & 0.003 \\
\hline Pseudorca crassidens* & - & - & - & - & 1 & 0.003 & - & - & - & - & - & - \\
\hline Globicephala macrorhynchus & - & - & - & - & 1 & 0.007 & - & - & - & - & 3 & 0.010 \\
\hline Unidentified dolphin & 1 & 0.007 & 12 & 0.025 & 3 & 0.013 & 1 & 0.045 & 6 & 0.039 & 3 & 0.024 \\
\hline Megaptera novaeangliae & 9 & 0.030 & 2 & 0.002 & - & - & - & - & - & - & - & - \\
\hline Unidentified whale & - & - & 3 & 0.002 & - & - & - & - & - & - & 1 & 0.004 \\
\hline
\end{tabular}

* Probable identification.

seismic operations, in intermediate and deep water, respectively.

Nighttime visual observations: Approximately one-third of all observation effort (187 h or $1549 \mathrm{~km}$ ) occurred during darkness. Nighttime visual monitoring took place during $50 \%$ of nighttime seismic operations. Six nighttime visual detections occurred (Table 1), two of which were detected with the NVD. PAM initially detected three of these groups and alerted the visual observers. Observers subsequently sighted two groups with the naked eye and one group with the NVD. Another two groups were initially sighted by the naked eye, and one group was spotted with the naked eye and the NVD after observers heard splashing near the bow. All nighttime sightings appeared to be small groups of either pantropical spotted or unidentified dolphins seen within $30 \mathrm{~m}$ of the Ewing's bow in $\mathrm{Bf} 1-4$ while the GI airguns were operating.

Passive acoustic monitoring: Approximately equal amounts of PAM effort occurred during daylight (324 h or $2672 \mathrm{~km}$ ) and darkness (309 h or $2529 \mathrm{~km}$ ). Nearly all $(96 \%)$ PAM effort took place during seismic operations. Overall, 217 acoustic detections were made: 90 during the day and 127 during darkness. The nighttime acoustic detection rate (0.05 detections $/ \mathrm{km})$ was significantly higher than the daytime detection rate $\left(0.04 / \mathrm{km} ; \chi^{2}=\right.$ 8.51, $\mathrm{P}=0.0035)$.

Most ( $\mathrm{n}=194$ or $89 \%$ ) of the 217 acoustic detections were unidentified dolphins (Table 1; Fig. 2). The other 23 detections were confirmed to species by simultaneous visual observations and consisted of pantropical spotted dolphins $(\mathrm{n}=17)$, spinner dolphins $(\mathrm{n}=3)$, common bottlenose dolphins $(\mathrm{n}=2)$, humpback whales $(\mathrm{n}=$ $2)$, short-finned pilot whales $(\mathrm{n}=1)$, and probable false killer whale $(n=1)$. There may have been additional vocalizations of short-finned pilot whales during a detection of unidentified dolphins, but this was uncertain. No acoustic detections were identified by acoustic recognition alone. When acoustic and visual detections could be matched, animals were first detected acoustically $59 \%$ of the time (18 of 30 cases). The total number of acoustic detections (217) was about three times higher than the total 


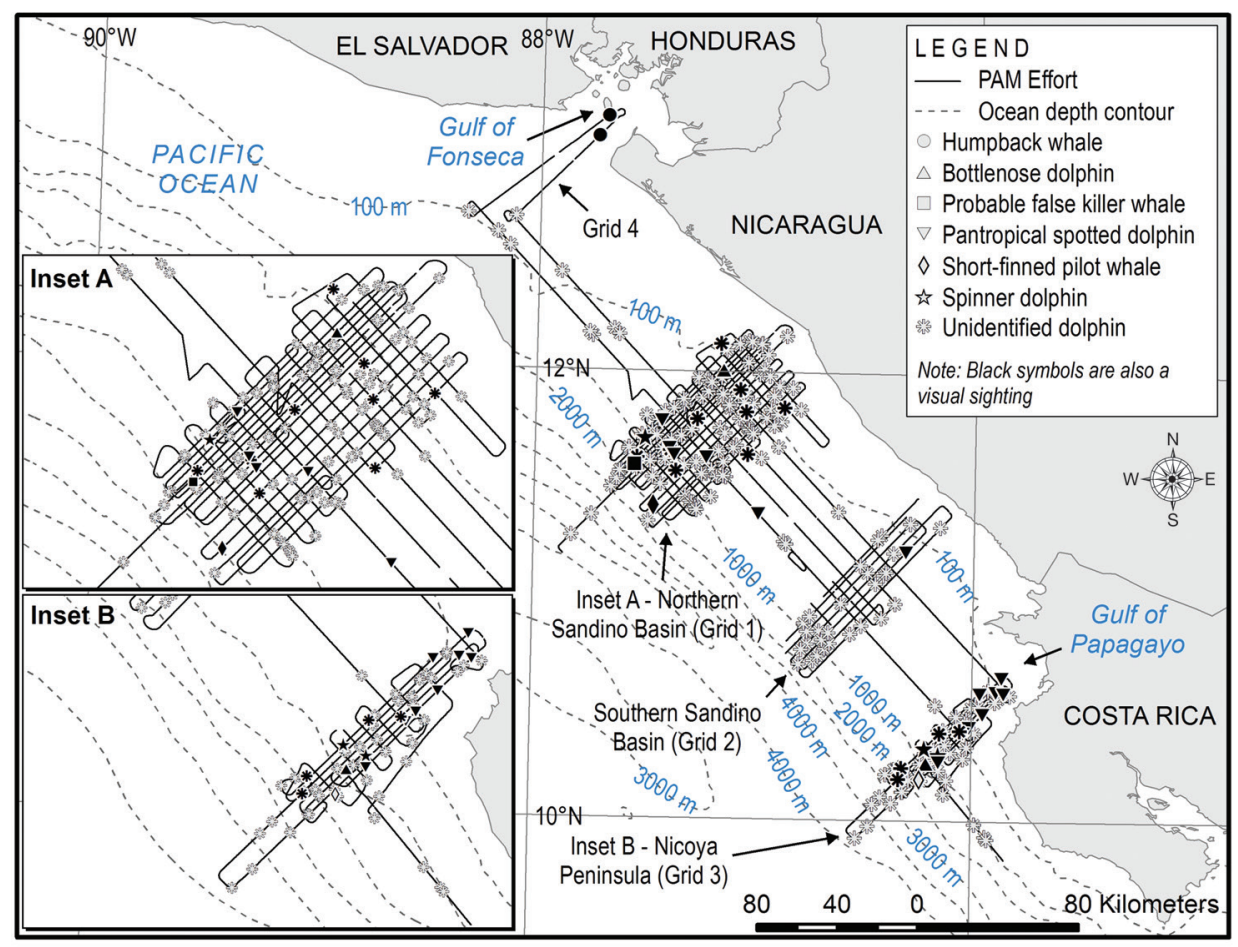

Fig. 2. Locations of cetacean acoustic detections made during the L-DEO ETP seismic survey, 21 November-22 December 2004.

number of visual sightings (81). Even when only daytime effort was considered, acoustic detection rates were twice as high $(0.04$ detections $/ \mathrm{km})$ as unadjusted sighting rates $(0.02$ sightings $/ \mathrm{km})$.

Power-and shut-downs implemented: A total of eight power downs to a single airgun and four complete shut downs of the airgun array were implemented during the survey following mitigation protocol. In an unusual encounter based on our combined extensive seismic mitigation and monitoring experience, a single pantropical spotted dolphin was sighted repeatedly over a period of $\sim 26 \mathrm{~h}$ on 23-24 November apparently following the Ewing, while the GI airguns were both on and off. This dolphin was seen in the Gulf of Papagayo off the Nicoya Peninsula, Northwestern Costa Rica (Fig. 1). It approached the Ewing and its operating GI airguns on several occasions to within $20 \mathrm{~m}$; the GI airguns were shut down twice and reduced in volume (powered down) once for this individual following the mitigation protocol. In addition, both a power down and a subsequent shut down (without resumption of operations in between) were implemented for a group of two humpback whales, and one additional shut down occurred for one other humpback whale. The remaining six power downs were implemented for a group of two humpbacks, a pod of bottlenose dolphins, a group of unidentified dolphins, and three pantropical spotted dolphin sightings.

\section{DISCUSSION}

Pantropical spotted, common bottlenose, and spinner dolphins were the most commonly observed cetacean species (in terms of individuals) during our 2004 fall vessel survey conducted primarily in coastal and continental slope waters off Nicaragua and Costa Rica. This is consistent with results of surveys conducted 
in the general region during July-December 1986-2005 (Ferguson \& Barlow, 2001; MayCollado et al., 2005; Hamilton et al., 2009), May 2005-April 2006 (Martínez-Fernández et al., 2011), and January-March 2015 (De Weerdt \& Pouey-Santalou, 2015). During surveys of Golfo Dulce in Southern Costa Rica during January-February 2010 and July-August 2011, common bottlenose and pantropical spotted dolphins were the most frequently sighted cetacean species (Bessesen, 2015).

We were unable to distinguish between the offshore and coastal subspecies ( $S$. a. graffmani) of pantropical spotted dolphin, as our vessel was not able to follow cetaceans for close inspection though both forms could occur there (Hamilton et al., 2009). Of the two spinner dolphin subspecies that may occur in the survey area, $S$. l. centroamericana is considered the most likely, though Eastern spinner dolphins $(S . l$. orientalis) are also possible (Rodríguez-Fonseca, 2001; May-Collado et al., 2005; Hamilton et al., 2009). We were also unable to differentiate the two spinner dolphin forms during the survey.

Although we detected few common or Risso's dolphins and no striped dolphins, they were frequently reported during previous surveys in the region (Ferguson \& Barlow, 2001; May-Collado et al., 2005; Hamilton et al., 2009). The paucity of sightings of the latter species may be related to the different seasonal timing of our survey (late fall vs. summer/fall for other studies), and/or the species' preferences for relatively deep and/or offshore waters (Jefferson, Webber, \& Pitman, 2015). Humpback whales and a possible minke whale were the only large whale species we saw, though blue (B. musculus), fin (B. physalus), and Bryde's whales (B. edeni) have been reported previously from the study region (Wade \& Gerrodette, 1993; Stafford, Nieukirk, \& Fox, 1999, a, b; May-Collado et al., 2005).

Similar to humpback whale sightings made off Nicaragua during our survey, studies off Costa Rica have shown that humpbacks occur predominantly within neritic waters $<200$ m deep (May-Collado et al., 2005), with most sightings in water $<50 \mathrm{~m}$ deep (Rasmussen, Calambokidis, \& Steiger, 2011). To our knowledge, concentrations of humpback whales including singing humpbacks, such as those detected during our study, have not previously been reported in the Gulf of Fonseca; this area could thus represent important wintering habitat for humpback whales off Central America. Other reported occurrences near the Gulf of Fonseca include one sighting off El Salvador on 28 February 1999 (Rasmussen, 2006; Rasmussen et al., 2011), and nine sightings of 17 humpbacks off Nicaragua's Cosigüina Peninsula between 26 February-16 March 2004 (Rasmussen, 2006). No humpback whales were sighted off Western Guatemala, El Salvador, Nicaragua, or Costa Rica during July-December 1986-1996 surveys (Ferguson \& Barlow, 2001). More recently in January-March 2016, 24 humpback whales were observed off Western Nicaragua, with one mother-calf pair seen just North of Nicaragua (J. De Weerdt, unpublished data). Relatively few other humpback whale sightings have previously been reported off Nicaragua during the boreal late fall-winter.

All the above-mentioned sightings near Nicaragua were presumably Northern Hemisphere humpback whales based on location, timing, and calf presence (Acevedo \& Smultea, 1995; Clapham \& Mead, 1999; Rasmussen, 2006). However, Southern Hemisphere humpbacks, presumably from the Southern Pacific Breeding Stock G have also recently been seen off Southwestern Nicaragua near San Juan del Sur during mid- to late-August, including four mother-calf pairs, suggesting a Northern extension of this stock (De Weerdt \& Pouey-Santalou, 2015). The previous Northern-most spatial overlap for Northern and Southern populations was reported for Costa Rica (Steiger, Calambokidis, Sears, Balcomb, \& Cubbage, 1991; Acevedo \& Smultea, 1995; May-Collado et al., 2005; Rasmussen, 2006).

The only humpback whale mother-calf pair during our survey was seen off Costa Rica on 25 November off the Nicoya Peninsula near the Gulf of Papagayo (bottom depth $85 \mathrm{~m}$, $10^{\circ} 39^{\prime} 54^{\prime \prime}$ N-85 $\left.56^{\prime} 24^{\prime \prime} \mathrm{W}\right)$. Although the date 
of this calf sighting is early for the reported calving period among Northern Hemisphere humpbacks, the location and small size of the calf relative to the mother (approximately one-third the mother's body length) suggest that the pair was likely from the Northern Hemisphere population. The Nicoya Peninsula is considered a relatively high-use area for wintering Northeastern Pacific humpbacks during January-March, with most calves born in December-February (Townsend, 1935; Nishiwaki, 1966, Rice, 1978; Steiger et al., 1991; Calambokidis et al., 2000; May-Collado et al., 2005; Rasmussen et al., 2011). In contrast, Southern Hemisphere humpbacks winter off Central America during August-early October with peak calving in July-August (Townsend, 1935; Chittleborough 1965; Rice, 1978; MayCollado et al., 2005; Rasmussen et al., 2007).

The effectiveness of NVDs for seeing cetaceans at night had previously been questionable due to the lack of nighttime sightings during multiple other L-DEO surveys. However, NVD ground-truthing experiments had been attempted during previous L-DEO surveys to assess how far observers could see various targets (Holst, Smultea, Koski, \& Haley, 2005). The nighttime sightings made during the cruise suggest that monitoring during darkness, including use of NVDs, has some limited success in detecting cetaceans close to the vessel under certain nighttime conditions.

Acoustic detection rates were higher than visual sighting rates; this is typical for joint visual/acoustic surveys, especially during poor sighting conditions (Thomas, Fisher, Ferm, \& Holt, 1986; Fristrup \& Clark, 1997; Norris, McDonald, \& Barlow, 1999; Barlow \& Taylor, 2005). Variability in vocalization rates and call intensity can dramatically affect detection rates of animals during surveys. In addition, these factors were potentially confounded by the presence of the Ewing and its associated seismic activity. Periods of darkness and times with poor sighting conditions are situations in which PAM can greatly enhance the ability to detect the presence of calling cetaceans. For example, our visual detection rates of cetaceans off Southern Nicaragua were low, presumably related to the poor sighting conditions; however, the number of acoustic detections was relatively high.

Vessel-based cetacean surveys have been conducted systematically in the wider ETP for over 20 years prior to our survey, primarily during summer-early fall (Polacheck, 1987; Wade \& Gerrodette, 1993; Ferguson \& Barlow, 2001; May-Collado et al., 2005; Hamilton et al., 2009). However, there is little detailed information about cetacean distribution in shelf $v s$. slope waters of Pacific Central America during late fall. Although predictive modeling of cetacean densities within the ETP is now available (Forney et al., 2012; Pardo et al., 2015), the models are based on limited effort in shelf and slope waters, particularly at the time of our survey. The L-DEO survey obtained data that provides a comparison of the encounter rates of common cetacean species in shelf and slope waters off Central America, thereby contributing to the overall knowledge for the region. Some of the differences observed during the L-DEO study compared to previous studies may be related to differences in effort including inter-annual variation, time of year, water depth, and/or geographical location.

In addition, sightings and detections made during seismic periods were likely influenced by the Ewing's airgun operations. Localized and short-term behavioral responses such as movement toward or away from the sound source or a change in vocalization rates have been reported for some cetaceans during seismic surveys (Richardson et al., 1995; Gordon et al., 1998; Nowacek et al., 2007; Southall et al., 2007; Barry, Cucknell, \& Clark, 2012; Castellote, Clark, \& Lammers, 2012; Blackwell et al., 2013, 2015; Thompson et al., 2013; Robertson et al., 2013; Cerchio, Strindberg, Collins, Bennett, \& Rosenbaum, 2014; Pirotta, Brookes, Graham, \& Thompson, 2014; Wole \& Myade, 2014; Dunlop et al., 2015, 2016; Muir et al., 2015, 2016; Finneran et al., 2015; Gailey et al., 2016). However, the long-term consequences of airgun sounds on marine mammals are mostly unknown, and the effectiveness 
of mitigation measures are largely uncertain (Cato et al., 2013; Nowacek et al., 2013; Wright \& Consentino, 2015).

Our visual and acoustic detections indicated that at least two delphinids as well as humpbacks were relatively common in the study area, despite the Ewing's ongoing seismic operations. However, our comparisons between encounter rates during the survey should be interpreted with caution, as observer effort was $\sim 3.5$ times higher during seismic compared to non-seismic conditions. Furthermore, most of the non-seismic effort occurred while in transit to and from the actual survey area, when the vessel speed was generally twice as fast as during seismic operations (9-11 vs. 4-5 kn). Thus, encounter rates during seismic $v s$. non-seismic periods may not be a reliable measure of potential effects of seismic. Despite these limitations, the information presented here contributes to our understanding of cetacean species occurrence and distribution based on concentrated search effort in specific areas off Nicaragua and Costa Rica where previous effort was limited, particularly in coastal and slope waters.

\section{ACKNOWLEDGMENTS}

This work was conducted under an Incidental Harassment Authorization issued to L-DEO by the U.S. National Marine Fisheries Service (NMFS), Office of Protected Resources, and was funded by L-DEO and the National Science Foundation (NSF). L-DEO provided the logistical support for this cruise and the associated marine mammal monitoring program. Vessel clearance was obtained for seismic survey effort in the exclusive economic zones of the Central American countries. We thank the crew of the Ewing and the geophysics team from the University of Texas, Institute of Geophysics, who helped make the program a success, and Mark Fitzgerald (LGL) for help with finalizing the manuscript.

\section{RESUMEN}

Avistamientos y detecciones acústicas de cetáceos durante un sondeo sísmico en aguas fuera de las costas de Nicaragua y Costa Rica, en Noviembre y Diciembre 2004. Aunque el ancho Pacífico Tropical Oriental ha sido sistemáticamente sondeado durante el verano/otoño, relativamente poco esfuerzo se ha aplicado tanto en aguas de la plataforma continental como el talud de Nicaragua y Costa Rica. Tales datos son útiles para establecer una información base y evaluar los cambios potenciales en la presencia y distribución relacionada tanto a factores naturales (ej., fenómeno de El Niño, cambio climático) como a factores antropogénicos. Un sondeo visual y acústico de cetáceos fue realizado como parte de un programa de monitoreo y mitigación durante un estudio académico de geofísica (sísmica) en las afueras de las costas de Nicaragua y Costa Rica durante Noviembre y Diciembre 2004. Aproximadamente 2067 cetáceos representantes de al menos siete especies fueron avistados en 75 grupos durante 373 h $(3416 \mathrm{~km})$ de observación diurna desde el buque de prospección sísmica (R/V) Maurice Ewing. La ballena jorobada (Megaptera novaeangliae) y el delfín manchado pantropical (Stenella attenuata) fueron las especies más frecuentemente avistadas (30\% de todos los grupos avistados); ambas fueron avistadas tanto en aguas de la plataforma continental $<100 \mathrm{~m}$ de profundidad como en aguas del talud. El delfín nariz de botella (Tursiops truncatus; con un $10 \%$ de los avistamientos) fue la tercera especie más avistada, solamente visto en aguas $>100 \mathrm{~m}$ de profundidad. Adicionalmente, se registraron avistamientos de delfines acróbatas (S. longirostris), delfines comunes de hocico corto (Delphinus delphis), calderones grises (Grampus griseus), ballenas piloto de aleta corta (Globicephala macrorhynchus) además de ballenas y delfines no identificados. También se registró un avistamiento no confirmado de una ballena de minke (Balaenoptera acutorostrata) y uno de un grupo de falsas orcas (Pseudorca crassidens). Un adicional de seis avistamientos de delfines (confirmándose en un $50 \%$ de ellos para la especie de delfín manchado pantropical) se observaron durante $187 \mathrm{~h}(1549 \mathrm{~km})$ de esfuerzo durante lapsos de oscuridad, dos de los cuales se detectaron a $30 \mathrm{~m}$ de la proa de la embarcación utilizando dispositivos de visión nocturna. Un total de 217 detecciones de cetáceos ocurrieron durante $633 \mathrm{~h}$ de monitoreo acústico pasivo. Una pequeña concentración de 12 ballenas jorobadas fue avistada en ocho grupos, y dos jorobadas fueron registradas cantando en el Golfo de Fonseca el 9 de Diciembre 2004. Para nuestro conocimiento, tal concentración de ballenas jorobadas, particularmente jorobadas cantando, no han sido reportadas previamente en esta área específica. Adicionalmente, una pareja de jorobadas madre-cría, probablemente de la población del Hemisferio Norte, fue avistada 
en las afueras de la costa de Costa Rica el 25 de Noviembre 2004. A pesar de que las tasas de avistamiento fueron significativamente distintas durante los periodos sísmicos y no sísmicos, incluso siendo corregidos según la probabilidad de detecciones relacionadas a las condiciones del mar, nuestro sondeo provee información que cubre vacíos previos de datos en la presencia de cetáceos en las aguas tanto de la plataforma como del talud continental fuera de las costas del Pacífico de América Central durante el otoño tardío.

Palabras clave: sondeo geofísico, monitoreo acústico pasivo, mamífero marino, Pacífico Tropical Oriental, América Central.

\section{REFERENCES}

Acevedo, A., \& Smultea, M. A. (1995). First records of humpback whales including calves at Golfo Dulce and Isla del Coco, Costa Rica, suggesting geographical overlap of Northern and Southern Hemisphere populations. Marine Mammal Science, 11, 554-560.

Barlow, J. (2015). Inferring trackline detection probabilities, $g(0)$, for cetaceans from apparent densities in different survey conditions. Marine Mammal Science, 31, 923-943.

Barlow, J., \& Taylor, B. L. (2001). Estimates of large whale abundance off California, Oregon, Washington, and Baja California based on 1993 and 1996 ship surveys. National Marine Fisheries Service Administrative Report LJ-01-03. 12 pp. Available from SWFSC, P.O. Box 271, La Jolla, CA 92038.

Barry, S. B., Cucknell, A. C., \& Clark, N. (2012). A direct comparison of bottlenose dolphin and common dolphin behaviour during seismic surveys when airguns are and are not being utilised. In A. N. Popper \& A. Hawkins (Eds.), The effects of noise on aquatic life (pp. 273-276). New York: Springer.

Bessesen, B. L. (2015). Occurrence and distribution patterns of several marine vertebrates in Golfo Dulce, Costa Rica. Revista de Biología Tropical, 63(Suppl. 1), 261-272.

Blackwell, S. B., Nations, C. S., McDonald, T. L., Greene, Jr., C. R., Thode, A. M., Guerra, M., \& Macrander, A. M. (2013). Effects of airgun sounds on bowhead whale calling rates in the Alaskan Beaufort Sea. Marine Mammal Science, 29, E342-E365.

Blackwell, S. B., Nations, C. S., McDonald, T. L., Thode, A. M., Mathias, D., Kim, K. H., Greene, Jr., C. R., \& Macrander, A. M. (2015). Effects of airgun sounds on bowhead whale calling rates: evidence for two behavioral thresholds. PLOS ONE, 10, e0125720.

Calambokidis, J., Steiger, G. H., Rasmussen, K., Urbán, R. J., Balcomb, K. C., Guevara, P., \& Darling, J. D.
(2000). Migratory destinations of humpback whales that feed off California, Oregon and Washington. Marine Ecology Progress Series, 192, 295-304.

Castellote, M., Clark, C. W., \& Lammers, M. O. (2012). Acoustic and behavioural changes by fin whales (Balaenoptera physalus) in response to shipping and airgun noise. Biological Conservation, 147, 115-122.

Cato, D. H, Noad, M. J., Dunlop, R. A., McCauley, R. D., Gales, N. J., Salgado Kent, C. P., Kniest, H., Paton, D., Jenner, K. C. S., Noad, J., Maggi, A. L., Parnum, I. M., \& Duncan, A. J. (2013). A study of the behavioural response of whales to the noise of seismic air guns: design, methods and progress. Acoustics Australia, 41, 88-97.

Cerchio, S., Strindberg, S., Collins, T., Bennett, C., \& Rosenbaum, H. (2014). Seismic surveys negatively affect humpback whale singing activity off northern Angola. PloS ONE, 9, e86464.

Chittleborough, R. G. (1965). Dynamics of two populations of the humpback whale, Megaptera nodosa (Bonnaterre). Australian Journal of Marine and Freshwater Research, 16, 33-128.

Clapham, P. J., \& Mead, J. G. (1999). Megaptera novaeangliae. Mammalian Species, 604, 1-9.

De Weerdt, J., \& Pouey-Santalou, V. (2015). New records of humpback whales in Nicaragua: extension of the migratory route of the Southern Pacific Breeding stock G? Proceedings of the 21st Biennial Conference on Marine Mammals, Society for Marine Mammology, San Francisco, CA, USA, 13-18 December 2015 (Abstract and oral presentation).

Dunlop, R. A., Noad, M. J., McCauley, R. D., Kniest, E., Paton, D., \& Cato, D. H. (2015). The behavioural response of humpback whales (Megaptera novaeangliae) to a 20 cubic inch air gun. Aquatic Mammals, 41, 412-433.

Dunlop, R. A., Noad, M. J., McCauley, R. D., Kniest, E., Slade, R., Paton, D., \& Cato, D. H. (2016). Response of humpback whales (Megaptera novaeangliae) to ramp-up of a small experimental air gun array. Marine Pollution Bulletin, 103, 72-83.

Ferguson, M. C., \& Barlow, J. (2001). Spatial distribution and density of cetaceans in the Eastern Tropical Pacific Ocean based on summer/fall research vessel surveys in 1986-96. National Marine Fisheries Service Administrative Report LJ-01-04. 61 pp. Available from SWFSC, PO Box 271, La Jolla, CA 92038.

Ferguson, M. C., Barlow, J., Fiedler, P., Reilly, S. B., \& Gerrodette, T. (2006). Spatial models of delphinid (family Delphinidae) encounter rate and group size in the eastern tropical Pacific Ocean. Ecological Modelling, 193, 645-662. 
Finneran, J. J., Schlundt, C. E., Branstetter, B. K., Trickey, J. S., Bowman, V., \& Jenkins, K. (2015). Effects of multiple impulses from a seismic air gun on bottlenose dolphin hearing and behavior. Journal of the Acoustical Society of America, 137, 1634-1646.

Forney, K. A., Ferguson, M. C., Becker, E. A., Fiedler, P. C., Redfern, J. V., Barlow, J.,... Ballance, L. T. (2012). Habitat-based spatial models of cetacean density in the eastern Pacific Ocean. Endangered Species Research, 16, 113-133.

Fristrup, K., \& Clarke, C. (1997). Combining visual and acoustic survey data to enhance density estimation. Report of the International Whaling Commission, 47, 33-936.

Gailey, G., Sychenko, O., McDonald, T., Racca, R., Rutenko, A., \& Bröker, K. (2016). Behavioural responses of western gray whales to a 4-D seismic survey off northeastern Sakhalin Island, Russia. Endangered Species Research, 30, 53-71.

Gordon, J., Moscrop, A., Carlson, C., Ingram, S., Leaper, R., Matthews, J., \& Young, K. (1998). Distribution, movements and residency of sperm whales off the Commonwealth of Dominica, Eastern Caribbean: implications for the Development and Regulation of the Local Whalewatching Industry. Report of the International Whaling Commission, 48, 551-557.

Hamilton, T. A., Redfern, J. V., Barlow, J., Ballance, L. T., Gerrodette, T., Holt, R. S.,... Taylor, B. L. (2009). Atlas of cetacean sightings for Southwest Fisheries Science Center cetacean and ecosystem surveys: 1986 - 2005. U.S. Department of Commerce, NOAA Technical Memorandum NMFS SWFSC-440.

Holst, M., Smultea, M. A., Koski, W. R., \& Haley, B. (2005). Marine mammal and sea turtle monitoring during Lamont-Doherty Earth Observatory's marine seismic program in the Eastern Tropical Pacific Ocean off Central America, November-December 2004. LGL Report TA2822-30 for Lamont-Doherty Earth Observatory of Columbia University, Palisades, NY, and NMFS, Silver Spring, MD, USA. Available from LGL Limited, King City, ON, Canada.

Jefferson, T. A., Webber, M. A., \& Pitman, R. L. (2015). Marine mammals of the world: comprehensive guide to their identification. San Diego, California, United States of America: Elsevier/Academic Press.

Martínez-Fernández, D., Montero-Cordero, A., \& MayCollado, L. J. (2011). Cetáceos de las aguas costeras del Pacífico norte y sur de Costa Rica. Revista de Biología Tropical, 59, 283-290.

May-Collado, L., Gerrodette, T., Calambokidis, J., Rasmussen, K., \& Sereg, I. (2005). Patterns of cetacean sighting distribution in the Pacific Exclusive Economic Zone of Costa Rica based on data collected from 1979-2001. Revista de Biología Tropical, $53,249-263$
May-Collado, L. J., \& Forcada, J. (2012). Small-scale estimation of relative abundance for the coastal spotted dolphins (Stenella attenuata) in Costa Rica: the effect of habitat and seasonality. Revista de Biología Tropical, 60 (Suppl. 2), 133-142.

Muir, J. E., Ainsworth, L., Joy, R., Racca, R., Bychkov, Y., Gailey, G., Vladimirov, V., Starodymov, S., \& Bröker, K. (2015). Distance from shore as an indicator of disturbance of gray whales during a seismic survey off Sakhalin Island, Russia. Endangered Species Research, 29, 161-178.

Muir, J. E., Ainsworth, L., Racca, R., Bychkov, Y., Gailey, G., Vladimirov, V., Starodymov, S., \& Bröker, K. (2016). Gray whale densities during a seismic survey off Sakhalin Island, Russia. Endangered Species Research, 29, 211-227.

Nishiwaki, N. (1966). Distribution and migration of the larger cetaceans in the North Pacific as shown by Japanese whaling results. In K. S. Norris (Ed.), Whales, dolphins and porpoises (pp. 171-191). Berkeley, CA: University of California Press.

Norris, T. F., McDonald, M., \& Barlow, J. (1999). Acoustic detections of singing humpback whales in the eastern North Pacific during their northbound migration. Journal of the Acoustical Society of America, 106, 506-514.

Nowacek, D. P., Thorne, L. H., Johnston, D. W., \& Tyack, P. L. (2007). Responses of cetaceans to anthropogenic noise. Mammal Review, 37, 81-115.

Nowacek, D. P., Bröker, K., Donovan, G., Gailey, G., Racca, R., Reeves, R. R., Vedenev, A. I., Weller, D. W., \& Southall, B. L. (2013). Responsible practices for minimizing and monitoring environmental impacts of marine seismic surveys with an emphasis on marine mammals. Aquatic Mammals, 39, 356-377.

Pardo, M. A., Gerrodette, T., Beier, E., Gendron, D., Forney, K. A., Chivers, S. J., Barlow, J., \& Palacios, D. M. (2015). Inferring Cetacean Population Densities from the Absolute Dynamic Topography of the Ocean in a Hierarchical Bayesian Framework. PLOS ONE, 10, e0120727.

Pavan, G., Fossati, C., Manghi, M., \& Priano, M. (2004). Passive acoustics tools for the implementation of acoustic risk mitigation policies. In P. G. H. Evans \& L. A. Miller (Eds.), Proceedings of the Workshop on Active Sonar and Cetaceans, 17th ECS Conference, March 2003 (pp. 52-58). European Cetacean Society Newsletter 42 Special Issue.

Pirotta, E., Brookes, K. L., Graham, I. M., \& Thompson, P. M. (2014). Variation in harbour porpoise activity in response to seismic survey noise. Biology Letters, 10, 20131090.

Polacheck, T. (1987). Relative abundance, distribution and inter-specific relationship of cetacean schools 
in the Eastern Tropical Pacific. Marine Mammal Science, 3, 54-77.

Rankin, S., Barlow, J., Oswald, J., \& Ballance, L. (2008). Acoustic studies of marine mammals during seven years of combined visual and acoustic line-transect surveys for cetaceans in the eastern and central Pacific Ocean. U.S. Department of Commerce, NOAA Technical Memorandum NMFS SWFSC-429. 58 pp.

Rasmussen, K. (2006). Comparison of two distinct populations of humpback whales (Megaptera novaeangliae) off Pacific Central America (M.Sc. Thesis). Moss Landing Marine Laboratories, San Francisco State University, Moss Landing, CA.

Rasmussen, K., Palacios, D. M., Calambokidis, J., Saborío, M. T., Dalla Rosa, L., Secchi, E. R.,...Stone, G. S. (2007). Southern Hemisphere humpback whales wintering off Central America: insights from water temperature into the longest mammalian migration. Biology Letters, 3, 302-305.

Rasmussen, K., Calambokidis, J., \& Steiger, G. H. (2011) Distribution and migratory destinations of humpback whales off the Pacific coast of Central America during the boreal winters of 1996-2003. Marine Mammal Science, 28, E267-E279.

Reilly, S. B. (1990). Seasonal changes in distribution and habitat differences among dolphins in the eastern tropical Pacific. Marine Ecology Progress Series, $66,1-11$.

Rice, D. W. (1978). The humpback whale in the North Pacific: distribution, exploitation, and numbers. In K. S. Norris, \& R. R. Reeves (Eds.), Report on a workshop in problems related to humpback whales (Megaptera novaeangliae) in Hawaii (pp. 29-44). Washington, D.C.: Report to the U.S. Marine Mammal Commission.

Richardson, W. J., Greene, Jr., C. R., Malme, C. I., \& Thomson, D. H. (1995). Marine Mammals and Noise. San Diego, CA: Academic Press.

Robertson, F. C., Koski, W. R., Thomas, T. A., Richardson, W. J., Würsig, B., \& Trites, A. W. (2013). Seismic operations have variable effects on dive-cycle behavior of bowhead whales in the Beaufort Sea. Endangered Species Research, 21, 143-160.

Rodríguez-Fonseca, J. (2001). Diversidad y distribución de los cetáceos de Costa Rica (Cetacea:Delphinidae,
Physeteridae, Ziphiidae y Balaenopteridae). Revista de Biología Tropical, 49(Suppl. 2), 135-143.

Southall, B. L., Bowles, A. E., Ellison, W. T., Finneran, J. J., Gentry, R. L., Greene Jr., C. R.,...Tyack, P. L. (2007). Marine mammal noise exposure criteria: initial scientific recommendations. Aquatic Mammals, $33,411-522$.

Stafford, K. M., Nieukirk, S. L., \& Fox, C. G. (1999a). Low-frequency whale sounds recorded on hydrophones moored in the eastern tropical Pacific. Journal of the Acoustical Society of America, 106, 3687-3698.

Stafford, K. M., Nieukirk, S. L., \& Fox, C. G. (1999b). An acoustic link between blue whales in the eastern tropical Pacific and the Northeast Pacific. Marine Mammal Science, 15, 1258-1268.

Steiger, G. H., Calambokidis, J., Sears, R., Balcomb, K. C., \& Cubbage, J. C. (1991). Movement of humpback whales between California and Costa Rica. Marine Mammal Science, 7, 306-310.

Thomas, J. A., Fisher, S. R., Ferm, L. M., \& Holt, R. S. (1986). Acoustic detection of cetaceans using a towed array of hydrophones. Report of the International Whaling Commission Special Issue, 8, 139-148.

Thompson, P. M., Brookes, K. L., Graham, I. M., Barton, T. R., Needham, K., Bradbury, G., \& Merchant, N. D. (2013). Short-term disturbance by a commercial twodimensional seismic survey does not lead to longterm displacement of harbour porpoises. Proceedings of the Royal Society B, 280, 20132001.

Townsend, T. H. (1935). The distribution of certain whales as shown by logbook records of American whaleships. Zoologica, 19, 3-49.

Wade, P. R., \& Gerrodette, T. (1993). Estimates of cetacean abundance and distribution in the Eastern Tropical Pacific (Report of the International Whaling Commission 43, 477-493)

Wole, O. G., \& Myade, E. F. (2014). Effect of seismic operations on cetaceans sightings off-shore Akwa Ibom State, south-south, Nigeria. International Journal of Biological and Chemical Sciences, 8, 1570-1580.

Wright, A. J., \& Consentino, A. M. (2015). JNCC guidelines for minimizing the risk of injury and disturbance to marine mammals from seismic surveys: we can do better. Marine Pollution Bulletin, 100, 231-239. 
